Article

\title{
Quantifying the Responses of Evapotranspiration and Its Components to Vegetation Restoration and Climate Change on the Loess Plateau of China
}

\author{
Linjing Qiu (D), Yiping Wu*(D), Zhaoyang Shi, Yuting Chen and Fubo Zhao \\ Department of Earth and Environmental Science, School of Human Settlements and Civil Engineering, \\ Xi'an Jiaotong University, Xi'an 710049, China; qiulinjing@mail.xjtu.edu.cn (L.Q.); \\ shizhaoyang888@stu.xjtu.edu.cn (Z.S.); chenyuting0112@stu.xjtu.edu.cn (Y.C.); zfubo789@xjtu.edu.cn (F.Z.) \\ * Correspondence: yipingwu@xjtu.edu.cn
}

Citation: Qiu, L.; Wu, Y.; Shi, Z.; Chen, Y.; Zhao, F. Quantifying the Responses of Evapotranspiration and Its Components to Vegetation Restoration and Climate Change on the Loess Plateau of China. Remote Sens. 2021, 13, 2358. https://doi.org/ $10.3390 / \mathrm{rs} 13122358$

Academic Editor: Pradeep Wagle

Received: 9 May 2021

Accepted: 13 June 2021

Published: 16 June 2021

Publisher's Note: MDPI stays neutral with regard to jurisdictional claims in published maps and institutional affiliations.

Copyright: (c) 2021 by the authors. Licensee MDPI, Basel, Switzerland. This article is an open access article distributed under the terms and conditions of the Creative Commons Attribution (CC BY) license (https:/ / creativecommons.org/licenses/by/ $4.0 /)$.

\begin{abstract}
Quantitatively identifying the influences of vegetation restoration (VR) on water resources is crucial to ecological planning. Although vegetation coverage has improved on the Loess Plateau (LP) of China since the implementation of VR policy, the way vegetation dynamics influences regional evapotranspiration (ET) remains controversial. In this study, we first investigate long-term spatiotemporal trends of total ET (TET) components, including ground evaporation (GE) and canopy ET (CET, sum of canopy interception and canopy transpiration) based on the GLEAM-ET dataset. The ET changes are attributed to VR on the LP from 2000 to 2015 and these results are quantitatively evaluated here using the Community Land Model (CLM). Finally, the relative contributions of VR and climate change to ET are identified by combining climate scenarios and VR scenarios. The results show that the positive effect of VR on CET is offset by the negative effect of VR on GE, which results in a weak variation in TET at an annual scale and an increased TET is only shown in summer. Regardless of the representative concentration pathway (RCP4.5 or RCP8.5), differences resulted from the responses of TET to different vegetation conditions ranging from -3.7 to $-1.2 \mathrm{~mm}$, while climate change from RCP4.5 to RCP8.5 caused an increase in TET ranging from 0.1 to $65.3 \mathrm{~mm}$. These findings imply that climate change might play a dominant role in ET variability on the LP, and this work emphasizes the importance of comprehensively considering the interactions among climate factors to assess the relative contributions of VR and climate change to ET.
\end{abstract}

Keywords: canopy evapotranspiration; community land model; ground evaporation; sensitivity experiment; spatiotemporal change

\section{Introduction}

Evapotranspiration (ET) is an essential component of both hydrological processes and surface energy exchange, which regulates water allocation to a land surface and thus plays an important role in water resource management [1,2]. Over the past three decades, dynamic changes in ET have been investigated extensively, revealing that global annual ET generally exhibits an increasing trend, but the magnitude of the increase varies between different regions [3,4]. Although it has been demonstrated that the local climate is a key driver of ET, land cover changes also play an important role in ET changes as the ET process can be modulated by vegetation cover by altering canopy interception, canopy transpiration, and ground evaporation (GE) [5-9]. Quantitatively identifying the causes of ET change is crucial to better understand hydrological process change due to climatic and anthropogenic impacts and to support decision makers in water resource planning and management.

In the context of climate change, many studies have tried to explain ET change $[10,11]$ and the responses of ET to various climatic factors, such as air temperature, solar radiation, precipitation, relative humidity, and wind speed, and these factors have been extensively 
investigated through observations and modeling; however, inconsistent conclusions have been drawn due to different climate zones, vegetation cover characteristics, and land management practices. For example, Guo et al. [12] assessed the sensitivity of ET to climate conditions based on 30 Australian locations in different climatic zones and concluded that wind and relative humidity are important variables for dry and humid catchments, respectively, while solar radiation has the greatest influence in warmer catchments. Wang et al. [13] found that wind speed was the most influential climatic variable for ET variability in China during 1961-2013, followed by the maximum daily temperature and sunlight duration. Pour et al. [14] reported that minimum temperature was the most influential factor for ET increase in peninsular Malaysia. Additionally, the rate of evaporation from open pans of water in the Northern Hemisphere has been steadily decreasing in past decades, which is in contrast with the expectation that a warming climate should cause an increase in the rate of evaporation from terrestrial open water bodies [15]. These findings reveal the complexity of the interaction between climate variables and ET and the uncertainty of existing knowledge.

The influences of land cover change on ET have also attracted much attention. There is consensus regarding the responses of ET to ecological restoration, i.e., afforestation is generally effective in improving land surface greenness and simultaneously decreases water yields and increases ET at the watershed scale [16-19]. In contrast, vegetation degradation exerts the opposite effects and leads to decreased ET [20-23]; however, the consequences of the restoration on ET at regional scales and in large river basins are still contentious $[18,24,25]$, because different land cover types have different biophysical effects due to different leaf area index (LAI), surface albedo, and root depth characteristics [16]. Moreover, stomatal responses to increased atmospheric $\mathrm{CO}_{2}$ concentrations vary in vegetation species, which correspondingly have different evaporation rates [26,27].

Identifying the contribution of climate change and vegetation coverage to ET change can help understand the causes of hydrological variations and explain the complex interactions between vegetation and climate. For this purpose, a number of attribution analyses have been conducted globally [1,21,28-30], and several types of approaches have been used to investigate the linkage of ET and various driving variables. Field observations are commonly used to quantify the impacts of climate and vegetation on ET, such as eddy covariance techniques, porometry, and lysimeters, and scintillometry, but these observation methods only cover small areas at the site level with short time spans; thus, the response mechanisms depending on the multiple vegetation cover and long-term climate evolution at the regional scale cannot be completely reflected. In recent years, remote sensing has been used to explore ET changes over a large spatial scale. An increasing number of ET products have been developed using land surface models and data assimilation based on remote sensing. These products have been largely used to detect ET trends [4] and statistically regress and correlate ET and environmental factors, such as land cover types, surface temperature, precipitation, and wind speed $[6,19,31,32]$. The correlation values cannot quantitatively reflect the contribution of certain factors to ET, and assuming linear relationships between ET and climatic factors is inconsistent with reality because the relationship is nonlinear [33].

With the advancement of computer techniques and the understanding of land and atmosphere coupling, large-scale hydrological models $[17,34]$, empirical models based on the Budyko framework [35], remote sensing- or energy balance-based ET models [36,37] and process-driven land surface models [38,39] have been created and applied to explore how environmental factors affect ET. In particularly, land surface models, as offline hydrologic models or land surface modules in tandem with Earth system models, have become powerful tools to study regional and global water cycles and climate change under heterogonous underlying surface conditions, because they have comprehensive biogeophysical parameterization mechanisms to capture the physical and biological interactions between land and atmosphere [40]. 
The Chinese Loess Plateau (LP), located in the transition zone between the southeast humid monsoon climate and northwest inland arid climate, covers an area of $6.4 \times 10^{5} \mathrm{~km}^{2}$ [41] The plateau has experienced severe vegetation degradation and soil erosion. To conserve soil and water resources in this region, a series of ecological restoration programs have been implemented since the 1960s, leading to increased vegetation coverage [41]. In particular, the largest program, called the Green for Grain Project, was launched in 1999, in which a large proportion of cropland was converted to forest and grassland. These actions largely modify the landscape and simultaneously caused decreases in both water discharge and sediment load [42]. Inevitably, large scale revegetation consumes more water from soil to maintain growth, accompanied by water loss through canopy transpiration [43]. Consequently, elucidating whether current vegetation restoration (VR) results in more water loss through ET in the LP has attracted the attention of many scholars [35,44-47]; however, the quantitative analysis of the contribution of VR and climate change to ET remains limited. In this study, we quantitatively evaluate the contribution of VR and climate change to the ET on the LP at the regional scale based on remote sensing products and the Community Land Model (CLM). The specific objectives here are to (1) detect the spatiotemporal change in the ET component, including GE and canopy ET (CET) during 1980-2018, (2) evaluate the CLM performance in simulating ET change in the LP region, and (3) quantitatively differentiate the contributions of climate change and VR to ET based on sensitivity simulations. The results can not only help us gain a better understanding of the hydrological effect of VR, but also provide decision makers with accurate and timely information for restoration planning and water resource management.

\section{Materials and Methods}

\subsection{Model Description}

All simulations used version 4.0 of the CLM (CLM4.0, hereafter referred to as CLM), which is coupled in Community Earth System Model version 1.2 (CESM1.2) and has been widely used in different ecosystems to evaluate the effects of land cover change, atmospheric deposition, and climate change on soil and surface waters in terrestrial ecosystems. The model parameterizes solar radiation partitioning, water transfer between the atmosphere and land surface, and soil organic matter dynamics. The CLM is designed to represent complex vegetation structures by applying plant functional types (PFTs), and seventeen PFTs are defined to capture plant physiology and ecological function, including needleleaf evergreen temperate trees, needleleaf evergreen boreal trees, needleleaf deciduous boreal trees, broadleaf evergreen tropical trees, broadleaf evergreen temperate trees, broadleaf deciduous tropical trees, broadleaf deciduous temperate trees, broadleaf deciduous boreal trees, C3 arctic grasses, C3 non-arctic grasses, C4 grasses, broadleaf evergreen shrubs, broadleaf deciduous temperate shrubs, broadleaf deciduous boreal shrubs, corn, wheat, and bare ground. The CLM allows multiple PFTs to coexist in each grid cell and land cover heterogeneity is specified through the foliage projective cover and LAI of each PFT. The soil profiles are divided into 15 layers with different depths from $0.007 \mathrm{~m}$ to $35.178 \mathrm{~m}$ in each grid cell. More information about the CLM and its theory can be found in the theoretical document [48].

\subsection{Data Sources}

The ET dataset, based on the Global Land Evaporation Amsterdam Model (GLEAM), was used to detect the spatiotemporal change in ET in the LP region during the period of 1980-2018. The GLEAM encompasses a set of algorithms which use satellite forcing data to separately estimate ET components, including GE, canopy transpiration, canopy evaporation, snow sublimation, and open-water evaporation [49]. Actual ET in the GLEAM is expressed as a function of potential ET and a stress factor that accounts for water limitations, and the potential ET is calculated based on the Priestley and Taylor equation [50]. The newest version, GLEAM-ET 3.3a, is provided with a $0.25^{\circ} \times 0.25^{\circ}$ latitude-longitude grid with a monthly temporal resolution (https://www.gleam.eu/; accessed on: 6 January 
2021). The GLEAM dataset has been widely used and verified to reflect the spatiotemporal characteristics of different terrestrial evaporation components. The GLEAM-ET dataset for the period from 1995-2004 was compared with ET components simulated by the CLM to evaluate the model performance in the LP region. The necessary atmospheric forcing data for driving the CLM were developed by Qian et al. [51], and these data have been widely tested and successfully used in different regions to explore the water cycle. The vegetation cover represented by PFT on the LP in 2000 and 2015 was acquired from satellite observation-based global land cover products at a $300 \mathrm{~m}$ resolution from the European Space Agency (ESA) as part of the Climate Change Initiative (CCI) land cover project (http:/ / www.esa-landcover-cci.org/; accessed on: 16 September 2020). The LAI data, obtained from the eight-day composite Global Land Surface Satellite (GLASS) product with a spatial resolution of $1 \mathrm{~km}$, were retrieved from the Moderate Resolution Imaging Spectroradiometer (MODIS) reflectance product (MOD09A1) [52] (downloaded from the National Earth System Science Data Center, http:/ / www.geodata.cn; accessed on: 9 September 2020). The LAI datasets were combined with the vegetation cover dataset to obtain the monthly LAI of each PFT using spatial overlay analysis.

\subsection{Experimental Designs}

Our analyses of the impact of VR on ET dynamics are based on two modern simulations that are performed using an offline CLM with fixed atmospheric forcing. The first simulation was designed for the control experiment (LC2000), representing vegetation cover in the LP region at the 2000 level. The model was forced with Qian atmospheric forcing data during 1972-2004, and the greenhouse gases were set at the 2000 level, with a $\mathrm{CO}_{2}$ concentration of $367 \mathrm{ppm}$. Then, the model was run for 99 years with three replicates of forcing data. The first two cycles were simulated for 66 years as spin-up periods to bring the carbon and nitrogen states of the land surface into dynamic equilibrium, and the third cycle was simulated for 33 years for analysis. The second simulation was a sensitivity simulation (LC2015) which considered the reality of VR in the LP region. The model set is similar to the control simulations, except that land surface conditions associated with vegetation distribution were substituted with the 2015 level. Finally, the differences were quantified by comparing two simulations to estimate the magnitude and direction of ET change due to VR.

To explore the impact of climate change on ET, high-frequency weather data under future representative concentration pathways (RCPs) of greenhouse gases were needed to use the CLM. Thus, the fully coupled CESM was run under a medium climate stabilization scenario (RCP4.5, stabilized radiative forcing at $4.5 \mathrm{~W} / \mathrm{m}^{2}$ in 2100) and high emission scenario (RCP8.5, increasing radiative forcing up to $8.5 \mathrm{~W} / \mathrm{m}^{2}$ in 2100) to generate 3-hourly weather data from 2005 to 2100 [53], including solar radiation, precipitation, humidity, wind, surface air pressure, and near-surface air temperature. We conducted four simulations that were designed by combining two future climate scenarios (RCP4.5 and RCP8.5) and two vegetation cover scenarios (LC2000 and LC2015). (1) LC2000RCP45: vegetation cover in 2000 with climate forcing under RCP4.5. (2) LC2000RCP85, vegetation cover in 2000 with climate forcing under RCP8.5. (3) LC2015RCP45, vegetation cover in 2015 with climate forcing under RCP4.5. (4) LC2015RCP85, vegetation cover in 2015 with climate forcing under RCP8.5.

\subsection{Data Analysis and Model Evaluation}

In this study, to focus on the contribution of vegetation to ET, we mainly analyzed the responses of GE, CET, and total ET (TET) to VR and climate change. CETs were defined as the sum of canopy evaporation and canopy transpiration, and TET was calculated as the sum of GE and CET. The spatiotemporal changes in GE, CET and TET during 1980-2018 were detected using linear regression analysis (least squares method), with a statistical significance analysis based on a t-test. To evaluate the model performance on the ET simulation, the CLM-simulated GE, CET and TET were compared with GLEAM-ET data sets 
from 1995 to 2004, and the statistical criteria, including the determination coefficient $\left(R^{2}\right)$ and root-mean-square error (RMSE), were calculated to indicate how well the simulated ET fit the GLEAM data sets. $\mathrm{R}^{2}$ mainly indicates the linear association, while the RMSE can reveal the deviations between different datasets [54]. To simplify the spatiotemporal information of ET under the combination of different vegetation coverages and future climates, empirical orthogonal function (EOF) analysis was used to extract the main spatiotemporal patterns of annual ET that were ranked based on their representations of data variance during the period of 1921-2100, and each pattern was associated with a series of time coefficients that described the time evolution of the particular spatial mode [55].

\section{Results}

\subsection{Historic Changes in Vegetation Coverage and ET on the LP}

Comparing the LAI values of the main vegetation cover types from 2000 to 2015 (Figure 1), most forests were located in the southeastern region of the LP, and the LAI clearly increased, with the area-averaged LAI changing from 1.2 in 2000 to 1.7 in 2015 (Figure 2). Grass was mainly distributed in the northern and central areas of the LP, and the LAI values of grassland also increased with values of 0.40 in 2000 and 0.55 in 2015. Although shrubs were sparsely distributed in the LP, the LAI increased from 1.20 to 1.50, and an evident increase mainly occurred in the eastern region of the LP. Crops covered the southernmost and eastern edges of the LP, and the area-averaged LAI in 2015 was higher than that in 2000 . These results show that the LAI values for all vegetation types clearly increased with the implementation of VR.

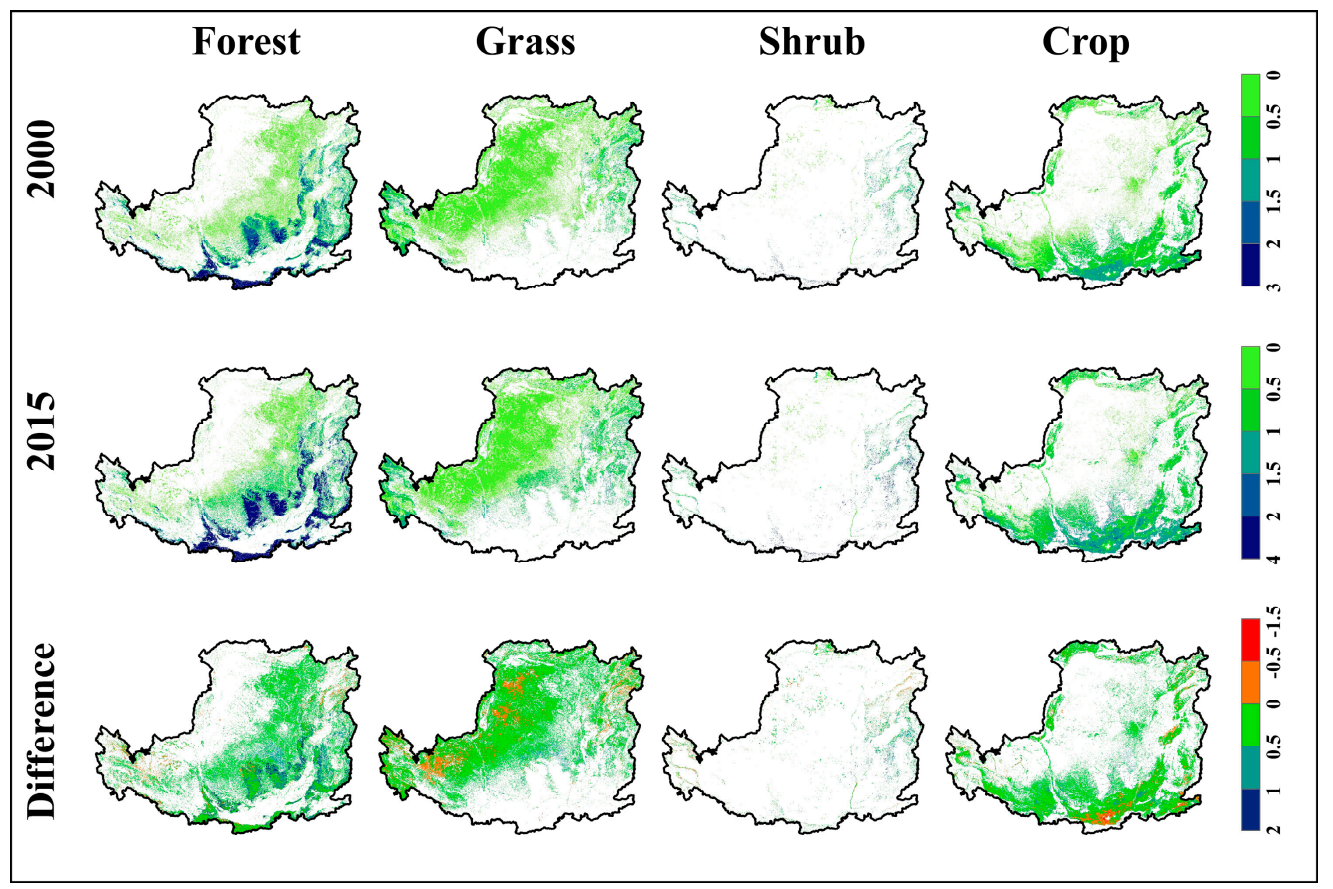

Figure 1. Spatial distribution of the LAI values of different vegetation types for 2000 and 2015. The bottom row shows differences between 2000 and 2015 (calculated as 2015 minus 2000). 


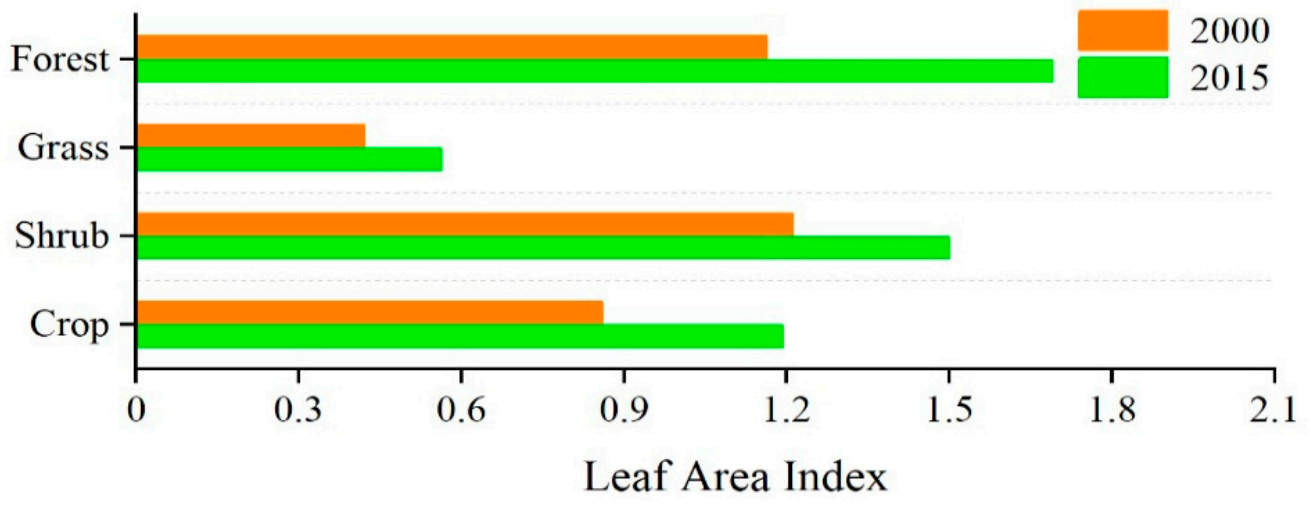

Figure 2. Comparison of the calculated average LAI values for different vegetation types between 2000 and 2015 on the LP.

Area-averaged GE on the LP for the period of 1980-2018 fluctuated interannually, ranging from $95 \mathrm{~mm}$ to $65 \mathrm{~mm}$, and the annual trend decreased with a gradient of $-0.52 \mathrm{~mm} /$ year (Figure 3a). Spatially, the average annual GE on the LP was higher in the northwestern regions with sparse vegetation, and the GE was lower in the eastern and southern regions with abundant vegetation (Figure 3b). Most regions of the LP showed significant decreasing trends with gradients ranging from $-1.2 \mathrm{~mm} /$ year to $-2.0 \mathrm{~mm} /$ year $(p<0.05)$ (Figure 3c). In contrast with GE, the area-averaged CET on the LP exhibited a significant increasing trend $(p<0.01)$, with a gradient of $2.1 \mathrm{~mm} /$ year (Figure $3 \mathrm{~d}$ ), and a larger increase occurred in the western and northern LP, where grassland and forestland clearly increased (Figure 3f). Although the southern LP had a higher annual average CET, the increasing trend was not statistically significant, even showing a decreasing trend in some areas. Similarly, the area-averaged TET increased significantly with a gradient of $1.58 \mathrm{~mm} /$ year $(p<0.01$ ) (Figure 3g), even though the increased CET was offset by a decreased GE. Overall, the spatiotemporal patterns of CET can reflect the corresponding pattern of TET (Figure 3h,i).

\subsection{Model Validation}

The CLM performance in the ET simulation was evaluated by comparing the simulated GE, CET, and TET values with GLEAM datasets from 1995 to 2004 (Figure 4). In general, the CLM performed well in capturing the dominant spatial pattern of annual average GE, CET and TET, showing a high magnitude in the southeastern LP and low magnitude in the northwestern LP; however, there were overestimations for GE (Figure 4a), which were clearly observed in the area-averaged monthly time series (Figure $4 \mathrm{~g}$ ). The simulated CET and TET had consistent fluctuating trends with the GLEAM-based monthly time series (Figure $4 \mathrm{~h}, \mathrm{i}$ ). To further evaluate the performances quantitatively, the $\mathrm{R}^{2}$ and RMSE between simulated and GLEAM-based area-averaged monthly series were calculated. The obtained high $\mathrm{R}^{2}$ (ranging from 0.89 to 0.92 ) and low RMSE (ranging from 4.72 to 7.73) indicated good performance for the CLM in reflecting the spatiotemporal pattern of ET on the LP. 

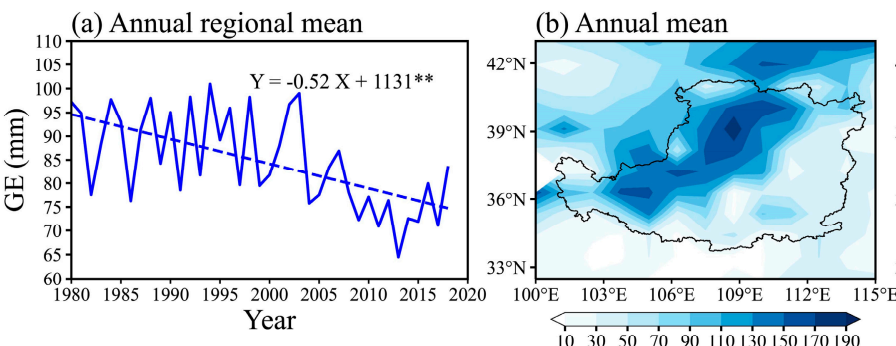

(c) Annual trends

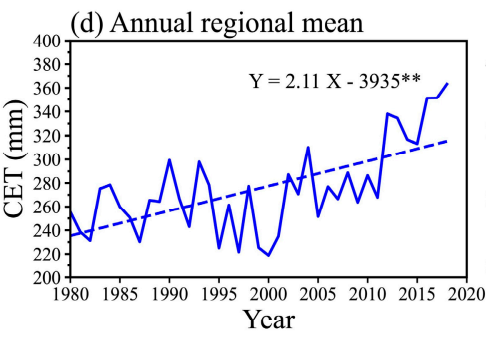

(e) Annual mean
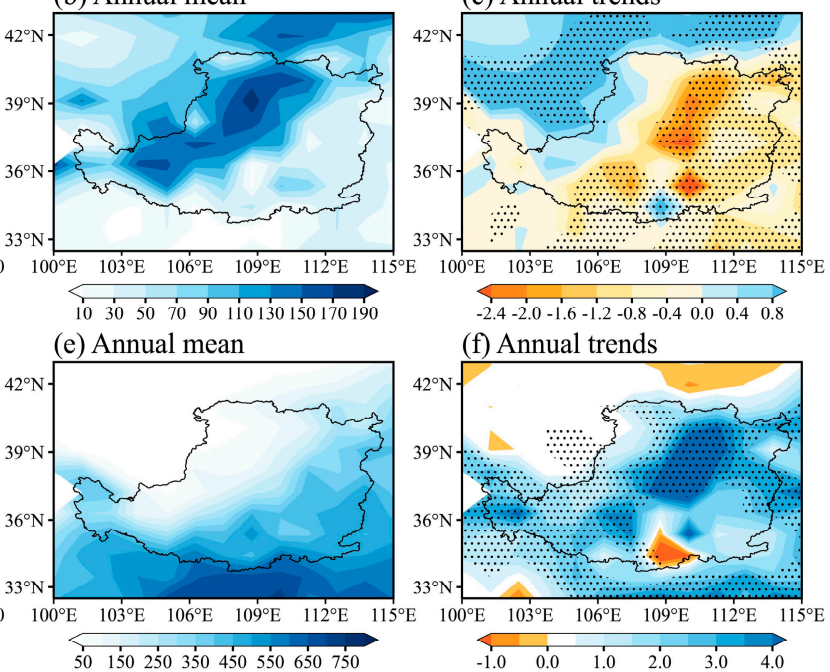

(f) Annual trends

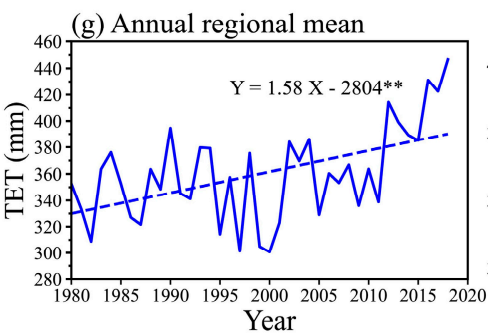
(h) Annual mean
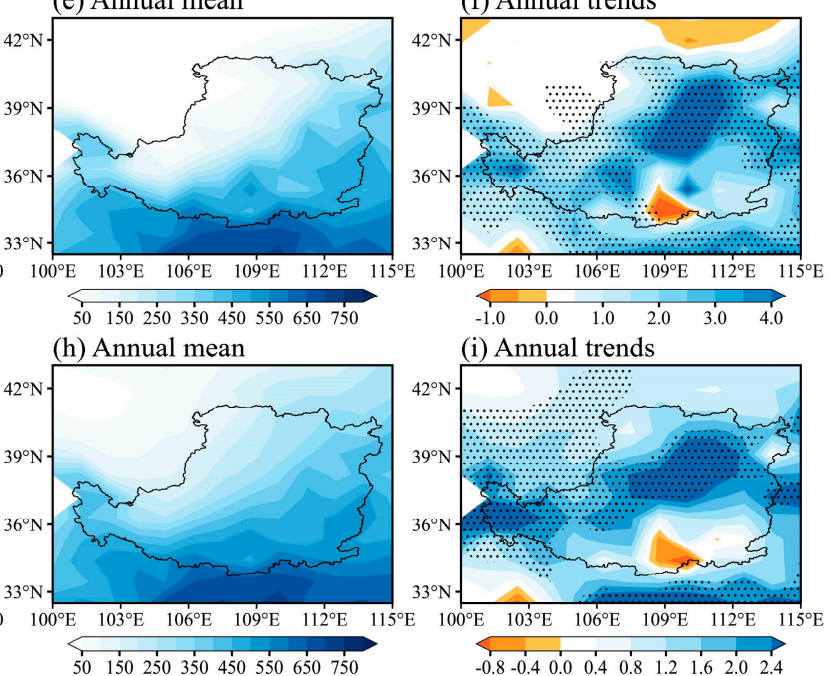

Figure 3. Spatiotemporal features of ET on the LP during the period of 1980-2018. The left column shows the area-averaged annual (a) ground evaporation, (d) canopy ET, and (g) total ET and their linear trends (unit: $\mathrm{mm}$ /year). Note that "***" indicates a statistically significant level $(p<0.01)$; the middle column shows the spatial pattern of annual mean (b) ground evaporation, (e) canopy ET and (h) total ET; and the right column shows the spatial pattern of linear trends (unit: $\mathrm{mm} /$ year) for the (c) ground evaporation, (f) canopy ET and (i) total ET. Areas with a significant change $(p<0.05)$ based on the $t$-test are stippled.

\subsection{Spatiotemporal Change in ET Attributed to VR}

Figure 5 depicts a comparison of the area-averaged annual ET for the two simulations. The simulated GE showed clear differences in their annual time series, and the GE of LC2015 was higher than that of LC2000; however, the CET showed opposite responses to vegetation coverage change, with a larger CET under LC2015 in comparison with LC2000. Consequently, the simulated TET did not show evident differences between LC2000 and LC2015, because the positive effect of VR on CET was offset by the negative effect of VR on GE. The spatial variation in annual average ET associated with VR is illustrated in Figure 6. The whole LP region, except for the small area of the central part and northern edge, showed decreased GE due to vegetation coverage changes from LC2000 to LC2015, particularly in the eastern LP, where GE decreased by more than $15 \mathrm{~mm}$, with a statistical significance level of 0.05 (Figure 6c). The CET showed opposite responses to vegetation coverage change compared with GE, and LC2015 had a higher CET in the western and southeastern LP, with magnitudes ranging from 2 to $6 \mathrm{~mm}$ (Figure 6f). Due to the offset between GE and CET in the process of VR, the TET variation at the annual scale showed a complex and inconsistent pattern in the LP region, with magnitudes ranging from -4 to $2 \mathrm{~mm}$ (Figure 6i). 
(a) GLEAM GE

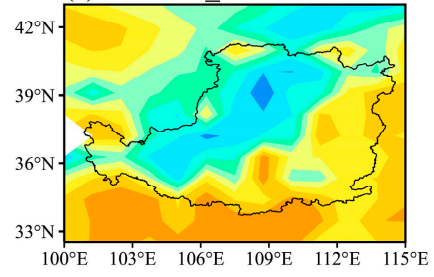

(d) SIM GE
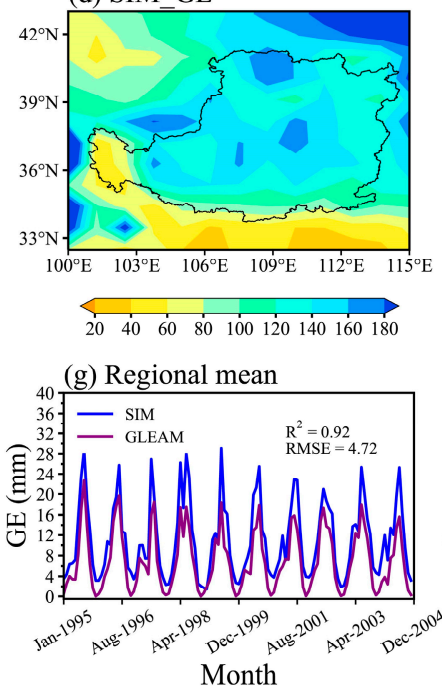

(b) GLEAM CET

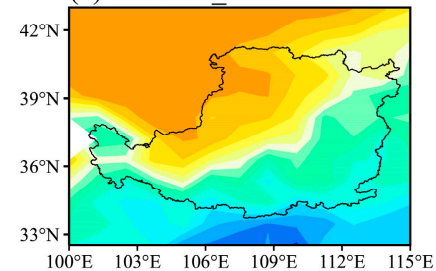

(e) SIM CET
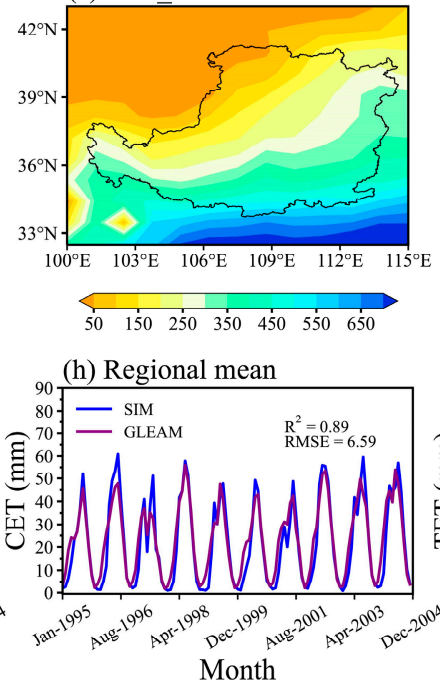

(c) GLEAM TET

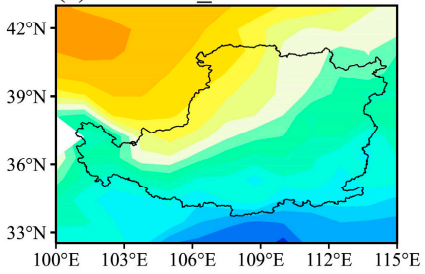

(f) SIM TET
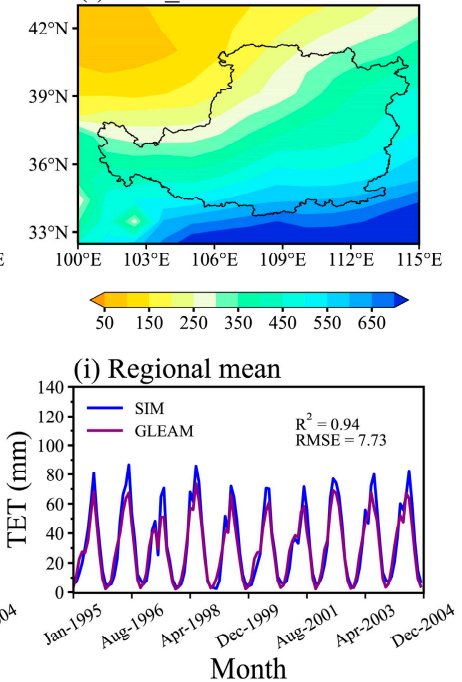

Figure 4. Comparison of the simulated mean annual ET by the CLM and GLEAM-based average values on the LP during 1995-2004. The top row (a-c) shows GLEAM-based ground evaporation, canopy ET, and total ET, respectively; the middle row (d-f) shows CLM-simulated ground evaporation, canopy ET, and total ET (unit: $\mathrm{mm}$ ), respectively; and the bottom row (g-i) shows the model performance expressed as the $\mathrm{R}^{2}$ and RMSE values for the area-averaged monthly time series for ground evaporation, canopy ET, and total ET, respectively.
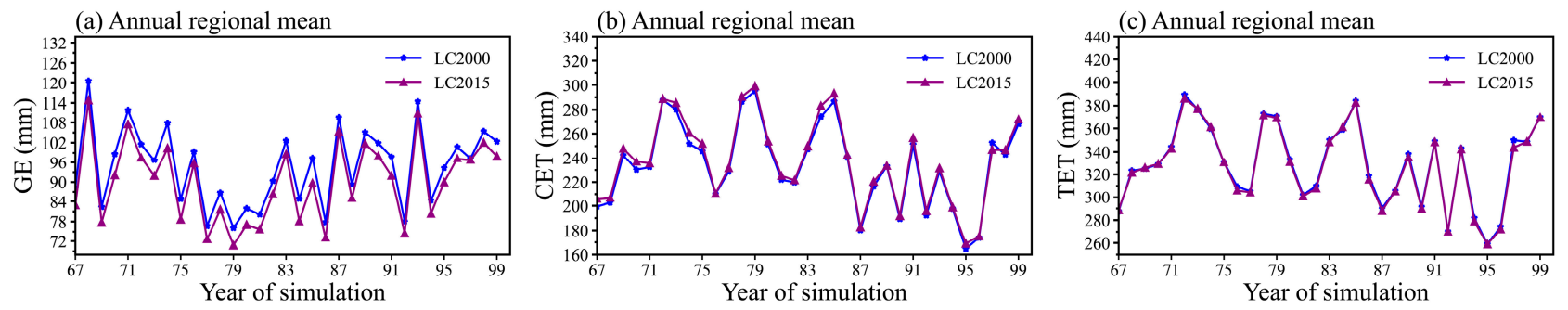

Figure 5. Area-averaged annual (a) ground evaporation, (b) canopy ET, and (c) total ET and their linear trends (unit: mm/year) for LC2000 and LC2015 on the LP. 

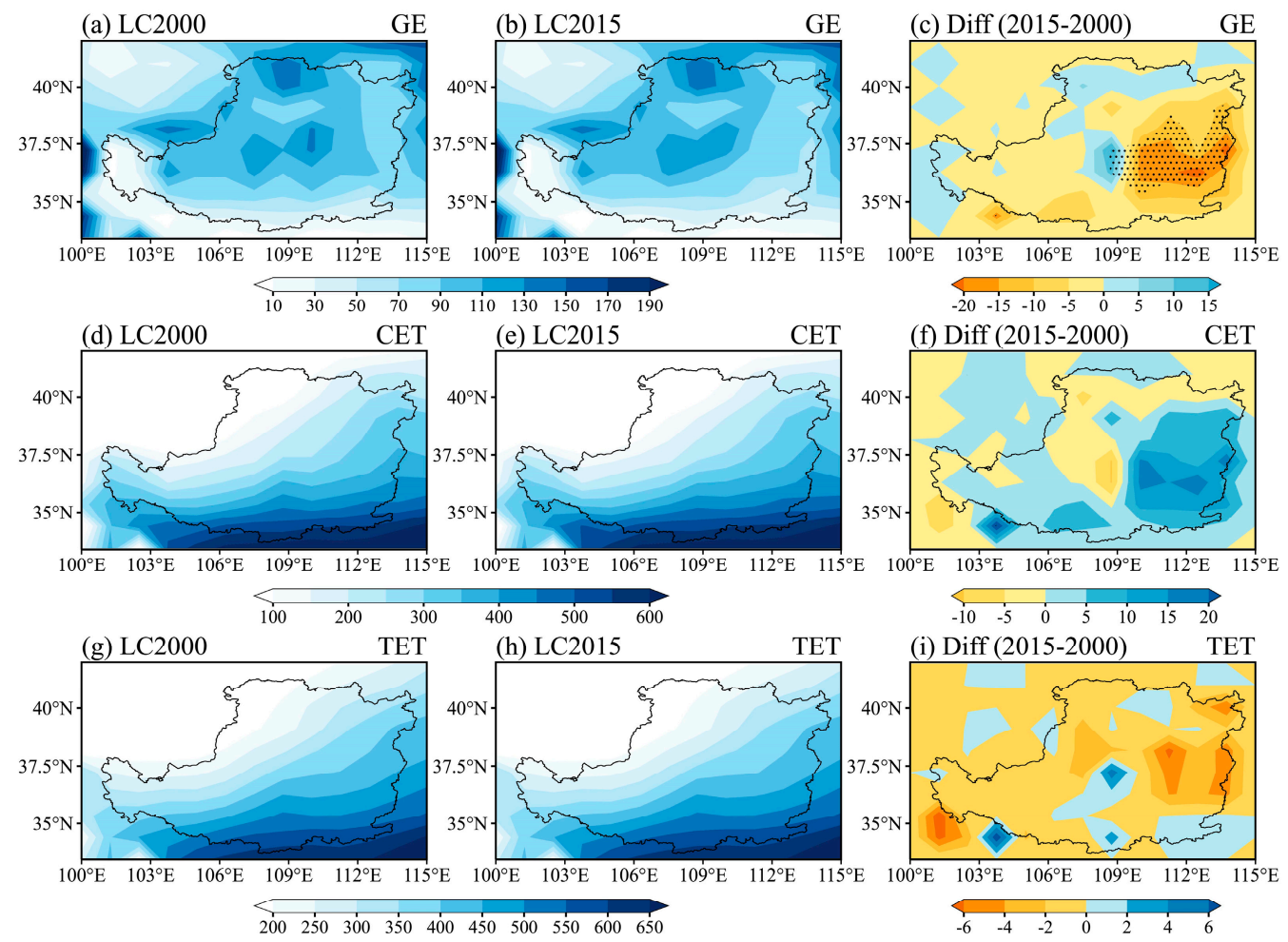

Figure 6. Spatial pattern of the simulated annual average ET (unit: $\mathrm{mm}$ ) and differences (LC2015 minus LC2000) between LC2000 and LC2015 on the LP. The first column (a,d,g) and second column $(\mathbf{b}, \mathbf{e}, \mathbf{h})$ show simulated ground evaporation, canopy ET and total ET under LC2000 and LC2015, respectively, and the third column $(\mathbf{c}, \mathbf{f}, \mathbf{i})$ shows differences in ground evaporation, canopy ET and total ET between LC2015 and LC2000. Areas with significant differences $(p<0.05)$ based on $t$-tests are stippled.

Seasonally, the spatial patterns of the responses of GE to vegetation change were similar among the four seasons, showing a consistent decrease in the eastern LP, while the magnitudes varied. June, July, and August (JJA) had the largest decreases, ranging from -3.20 to $-2.00 \mathrm{~mm}$, followed by September, October, and November (SON) ranging from -2.00 to $-0.80 \mathrm{~mm}$, and December, January, and February (DJF) with approximately $0.40 \mathrm{~mm}$, with a statistical significance level of 0.05 (Figure $7 \mathrm{~b}-\mathrm{d}$ ); however, the responses of CET varied among the four seasons. Nearly the whole LP region showed a dominant increase in CET in JJA with vegetation cover change from 2000 to 2015. The largest increase was found in the eastern LP, with a value of approximately $0.8 \mathrm{~mm}$, and the increased magnitudes decreased in the northwest direction (Figure 7f). During SON, mixed negative and positive responses were observed with magnitudes varying from $-0.8 \mathrm{~mm}$ in the north to $0.8 \mathrm{~mm}$ in the southeast (Figure $7 \mathrm{~g}$ ). Notably, the area with increased ET changed in DJF, showing a significant increase in the northeastern LP and a nonsignificant increase in the western LP, where the grassland clearly increased (Figure $7 \mathrm{~h}$ ). The overall change in TET is inconsistent among the four seasons due to the different responses of GE and CET. Nearly the whole LP exhibited increased TET in JJA (Figure 7j), while the TET decreased in the whole LP during March, April, and May (MAM) and SON with vegetation coverage changes from 2000 to 2015, particularly in the eastern LP (Figure 7i,k). During DJF, only a small area in the southern LP had a decreased TET, and most LP regions exhibited an increased TET (Figure 7l). 

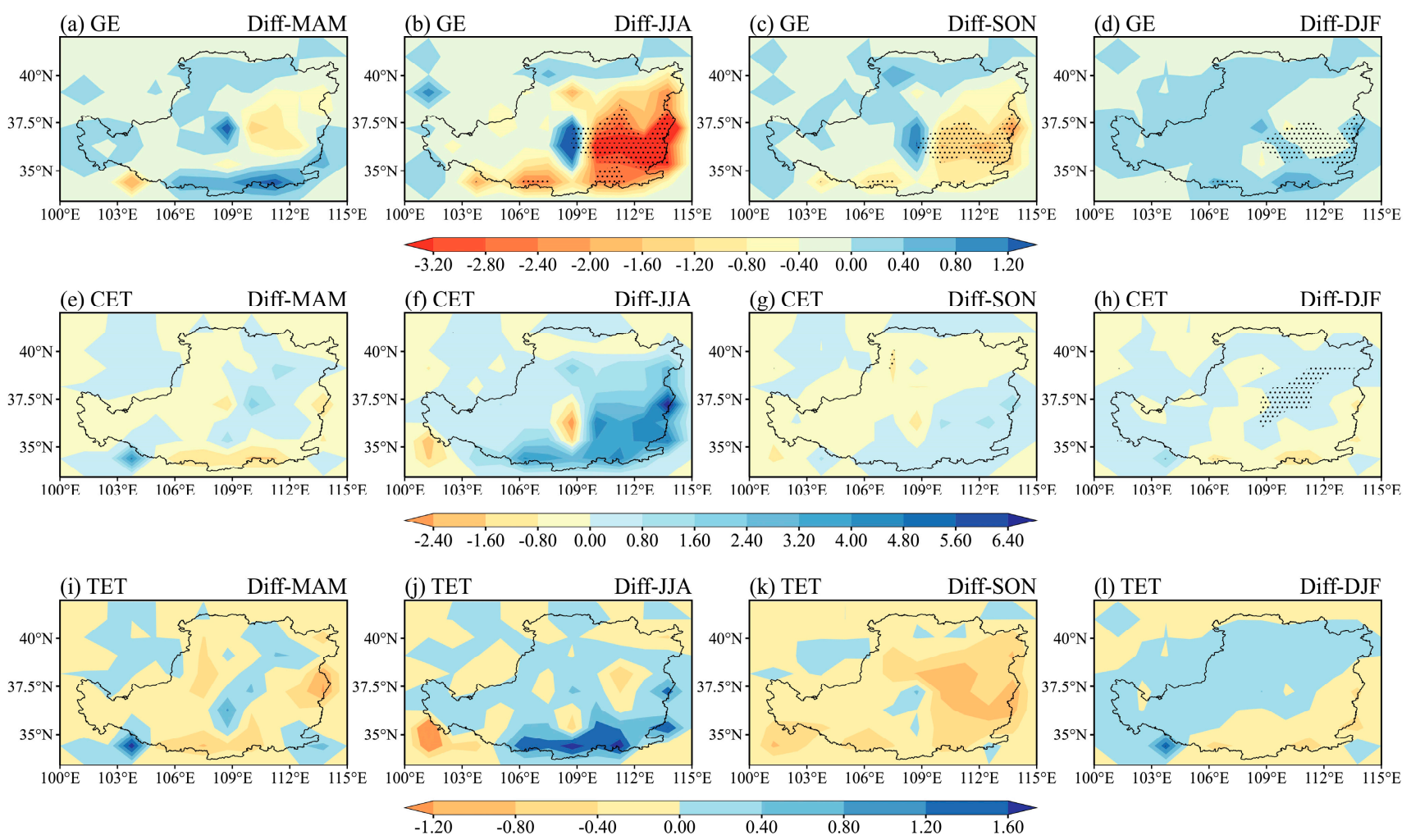

Figure 7. Spatial distributions of the seasonal differences (LC2015 minus C2000) in ET (unit: mm) between LC2000 and LC2015 on the LP. The first column (a,e,i), second column $(\mathbf{b}, \mathbf{f}, \mathbf{j})$, third column $(\mathbf{c}, \mathbf{g}, \mathbf{k})$ and fourth column $(\mathbf{d}, \mathbf{h}, \mathbf{l})$ show differences in the ground evaporation, canopy ET, and total ET for spring, summer, autumn, and winter, respectively. MAM, JJA, SOM, and DJF represent spring for the months from March to May, summer for the months from June to August, autumn for the months from September to November, and winter for the months from December to February of the following year, respectively.

\subsection{Quantifying the Contributions of Climate Change and VR to ET Change on the LP}

To evaluate the dynamic change in ET associated with VR and climate change over the $\mathrm{LP}$ region, the main leading modes of long-term variability were revealed using EOF analysis. We only presented the first EOF modes (EOF1) for analysis, because EOF1 explained more than $25 \%$ of the total ET variances, while the second EOF and third EOF modes explained less than $15 \%$ and $9 \%$ of the variance, respectively. The EOF1 modes of GE for LC2000RCP45 and LC2015RCP45 reflected consistent spatial patterns, showing opposite GE variations between the northern LP and zonal region extending from the central-western area to the east over the LP (Figure 8a,b). Combined with the EOF1 spatial pattern and temporal coefficients, GE exhibited an increasing trend before 2040 in the central-western and central-eastern area, while GE had a decreasing trend most of the time after 2040, in which LC2015RCP45 had a more pronounced change than LC2000RCP45. The EOF1 modes of CET for LC2000RCP45 and LC2015RCP45 showed consistent negative values in their respective spatial patterns, and the time coefficients featured downward trends (Figure 8c,d), indicating that CET increased during 2021-2100, with a more pronounced increase in LC2015RCP45. For TET, the spatial pattern of variability showed a positive value in the whole LP region (Figure 8e,f), which reflected an increasing trend of TET during 2021-2100 by combining with the upward trends exhibited in the time coefficients. 

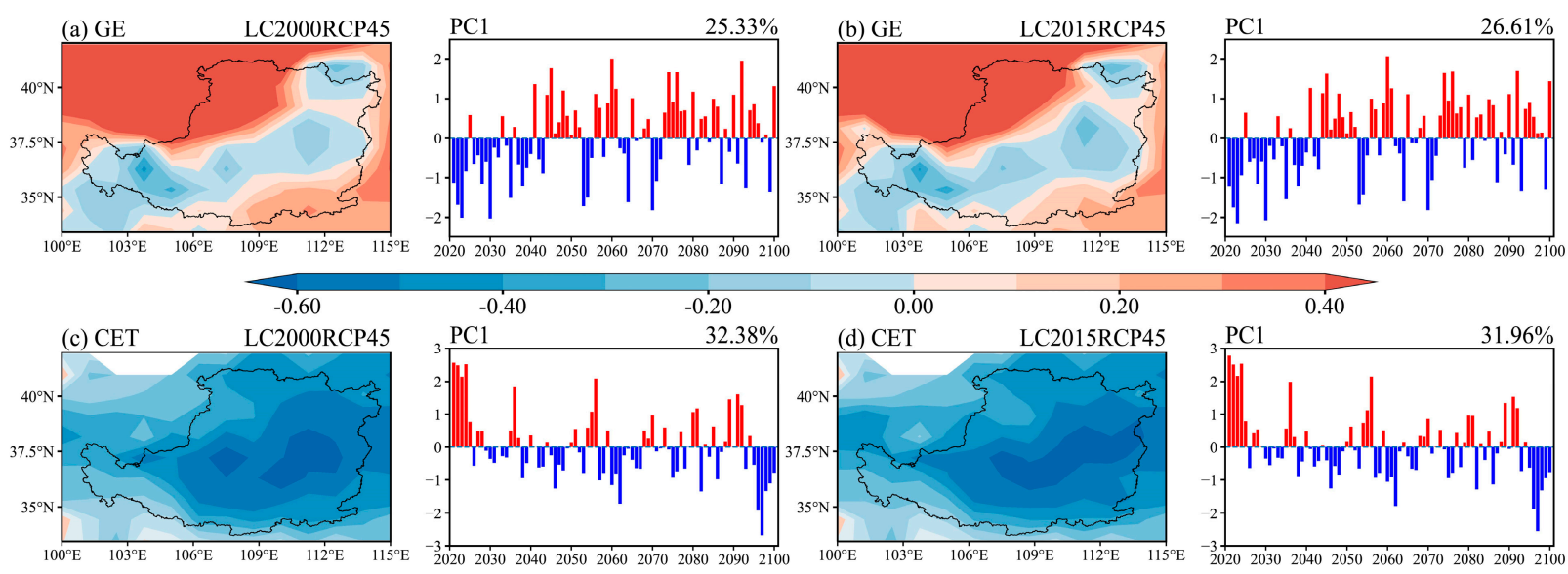

202020302040205020602070208020902100
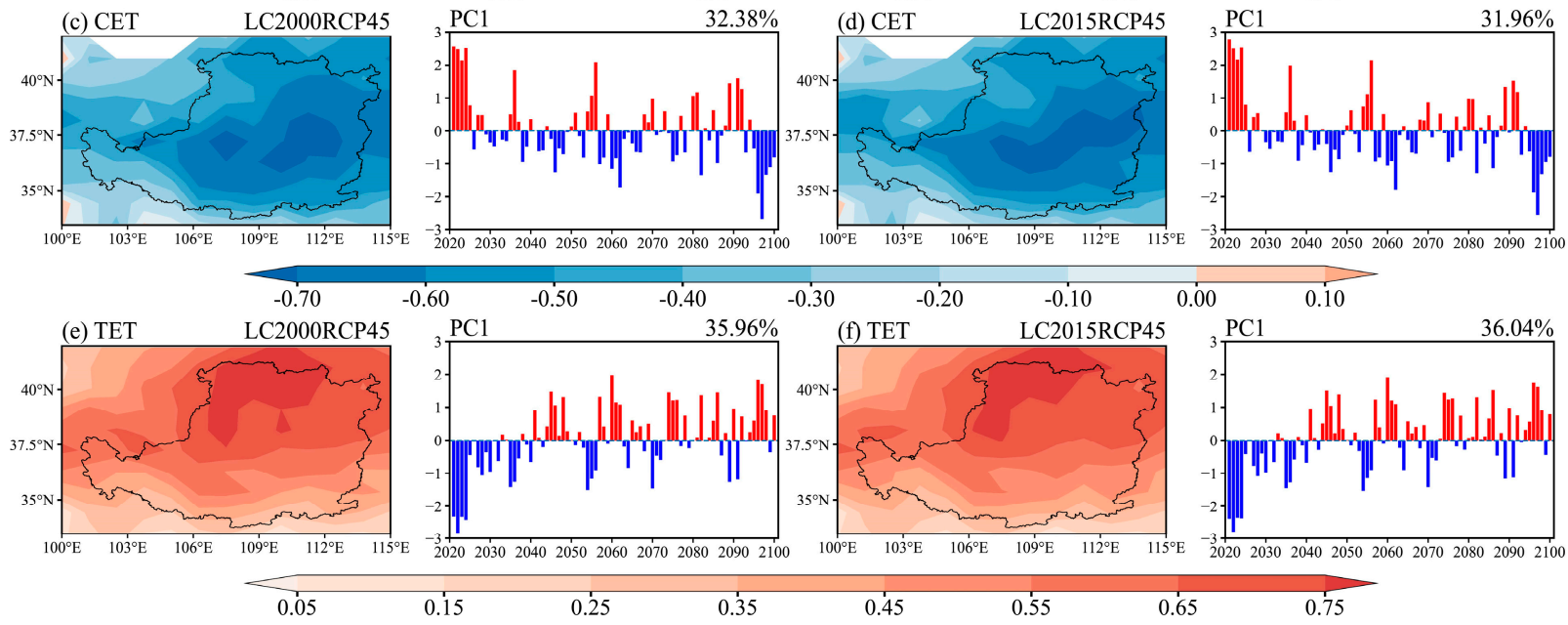

Figure 8. Comparison of spatial patterns and time series of the first EOF modes for responses of ET to different land cover conditions during 2021-2100 in the LP under the RCP4.5 scenario. The left two columns (a,c,e) and right two columns (b,d,f) show the spatiotemporal patterns of ground evaporation, canopy ET and total ET for the land cover conditions in 2000 and 2015 , respectively.

The spatial patterns of ET variabilities under the RCP8.5 scenario were noticeably different from those under the RCP4.5 scenario (Figure 9). The EOF1 mode of GE reflected consistent variations over the northwestern $\mathrm{LP}$, and opposite variations over the rest of the LP in LC2000RCP85 and LC2015RCP85 (Figure 9a,b). The time coefficients demonstrated the temporal behavior of this mode, characterized by an upward trend before 2060 and a downward trend after 2060, indicating that GE had an increasing trend before 2060 and a decreasing trend after 2060 in the southeastern LP, while the northwestern LP showed opposite trends. The spatial patterns of EOF1 for CET were different from those obtained from GE and showed consistent negative values in the whole LP (Figure 9c,d), and their time coefficients had downward trends during 2021-2100, reflecting general increasing trends of CET in LC2000RCP85 and LC2015RCP85. Notably, higher variabilities were detected in the southeastern LP under LC2000RCP85. For TET, both LC2000RCP85 and LC2015RCP85 had similar spatial patterns and time coefficients as CET, suggesting increased TET from 2021 to the end of the 21st century (Figure 9e,f).

Summarizing the results of the EOF analysis, we note that there were no clear differences in spatial patterns obtained from different land cover conditions under the same climate scenario, while the spatial pattern had noticeable differences under different climate scenarios with the same land cover conditions, indicating that the leading EOF modes of ET in LP were clearly climate-dependent.

To confirm the findings from the EOF analysis, we further calculated the contributions of VR and climate change on ET variation through four groups of simulations. Table 1 shows the unique effect of VR on ET in different stages during 2021-2100 on the LP. VR had a negative effect on GE, leading to a decrease in the area-averaged annual GE ranging from -5.9 to $-3.6 \mathrm{~mm}$ under RCP4.5, while VR had a positive effect on CET, causing an increase in the area-averaged annual CET ranging from 1.3 to $4.7 \mathrm{~mm}$. Under RCP8.5, the negative effect on GE and positive effect on CET intensified during 2021-2080. Since the negative effects on GE were larger than the positive effects on CET under both RCP4.5 and 
RCP8.5, the area-averaged annual TET showed a weak decrease, with magnitudes ranging from -3.7 to $-1.2 \mathrm{~mm}$. Regardless of vegetation cover in 2000 or 2015, climate change from RCP4.5 to RCP8.5 enhanced the area-averaged annual GE during the 2021-2080 period, with increased magnitudes ranging from 3.6 to $10.0 \mathrm{~mm}$ (Table 2). The area-averaged annual CET also had positive responses to climate change except for the period of 2041-2060, with increased magnitudes ranging from 5.0 to $68.4 \mathrm{~mm}$. As a result, the area-averaged annual TET under the two different land cover conditions evidently increased, with magnitudes ranging from 0.1 to $65.3 \mathrm{~mm}$.
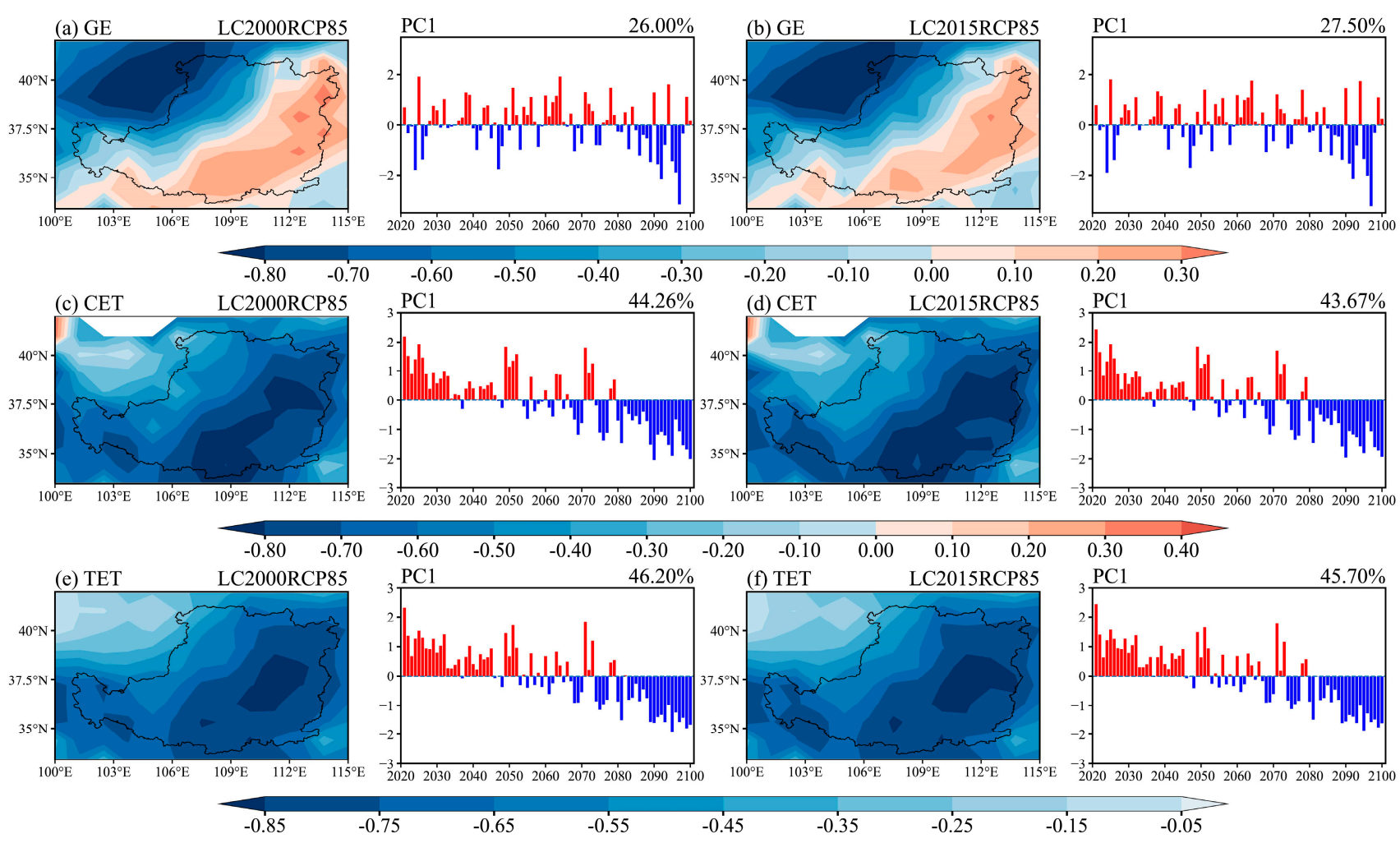

Figure 9. Comparison of spatial patterns and time series of the first EOF modes for responses of ET to different land cover conditions during 2021-2100 in the LP under the RCP8.5 scenario. The left two columns (a,c,e) and right two columns (b,d,f) show the spatiotemporal patterns of ground evaporation, canopy ET and total ET for the land cover conditions in 2000 and 2015 , respectively.

Table 1. Quantified contribution of VR to ET in different stages during 2021-2100 on the LP.

\begin{tabular}{cccccc}
\hline & & $\mathbf{2 0 2 1 - 2 0 4 0}$ & $\mathbf{2 0 4 1 - 2 0 6 0}$ & $\mathbf{2 0 6 1 - 2 0 8 0}$ & $\mathbf{2 0 8 1 - 2 1 0 0}$ \\
\hline RCP4.5 & GE & -4.7 & -4.5 & -4.7 & -5.9 \\
& CET & 2.4 & 1.3 & 2.6 & 4.7 \\
& TET & -2.3 & -3.2 & -2.1 & -1.2 \\
\hline \multirow{2}{*}{ RCP8.5 } & GE & -5.5 & -4.7 & -4.8 & -3.6 \\
& CET & 3.0 & 2.4 & 2.7 & -0.1 \\
& TET & -2.5 & -2.3 & -2.1 & -3.7 \\
\hline
\end{tabular}

The quantitative contribution was calculated as differences in simulated area-averaged annual ET between vegetation cover conditions of 2000 and 2015 under the same climate scenario (unit: $\mathrm{mm}$ ). 
Table 2. Quantified contribution of climate change to ET in different stages during 2021-2100 on the LP.

\begin{tabular}{cccccc}
\hline & & $\mathbf{2 0 2 1 - 2 0 4 0}$ & $\mathbf{2 0 4 1 - 2 0 6 0}$ & $\mathbf{2 0 6 1 - 2 0 8 0}$ & $\mathbf{2 0 8 1 - 2 1 0 0}$ \\
\hline $\begin{array}{c}\text { Vegetation } \\
\text { cover of 2000 }\end{array}$ & GE & 10.0 & 3.8 & 7.3 & -3.1 \\
& CET & 5.0 & -3.7 & 12.2 & 68.4 \\
& TET & 15.0 & 0.1 & 19.5 & 65.3 \\
\hline Vegetation & GE & 9.2 & 3.6 & 7.2 & -0.8 \\
cover of 2015 & CET & 5.6 & -2.6 & 12.3 & 63.6 \\
& TET & 14.8 & 1.0 & 19.5 & 62.8 \\
\hline
\end{tabular}
scenarios RCP8.5 and RCP4.5 under the same vegetation cover conditions (unit: $\mathrm{mm}$ ).

\section{Discussion}

ET is difficult to monitor at a regional scale due to complex underlying surfaces and large observation costs; thus, we adopted GLEAM-ET products to describe the dynamic changes in ET on the LP, and the spatial characteristics matched with the existing reports well [56,57]. Moreover, a significant increasing trend of TET was detected on the LP during 1980-2018, and the gradients were in line with the results (ranging from 1.34 to $3.45 \mathrm{~mm}$ /year) from previous studies at different spatial scales [45,58].

To quantify the influences of VR on ET changes at the regional scale on the LP, sensitivity simulations were conducted using realistic land use data rather than plausible scenarios. We found that the CET was enhanced under vegetation coverage change from 2000 to 2015, which was particularly evident in the southwestern and eastern LP, where the grassland and forestland clearly increased. This finding is well supported by many previous studies, where forested ecosystems are generally observed to have higher canopy transpiration than crop ecosystems, because forests have deeper roots and longer transpiration periods $[46,59]$. Another widely recognized reason is increased canopy interception, which contributes more to evaporative flux $[60,61]$.

A significant reduction in GE was found over regions with increased LAI of grass and forest. The reduction probably occurred because an increased canopy cover features more shadows and decreases the evaporative demand. There are two main driving factor variations involving decreased evaporative demand. On the one hand, increased canopy cover impedes radiation transmission to the ground surface, leading to a decrease in available heat for evaporation [62-64]. In this regard, Raz-Yaseef et al. [65] reported that GE fluxes measured in sun-exposed areas were on average double those in shaded areas. On the other hand, more precipitation was intercepted by increased canopy cover; thus, GE was decreased due to decreased water availability because precipitation is regarded as an important factor driving evaporation in water-limited areas $[19,66]$. Therefore, a larger reduction in GE relative to increased CET resulted in weak variation in TET at the annual scale due to the offset between the positive contribution and negative contribution of VR to TET. Notably, the TET increase of approximately $1.00 \mathrm{~mm}$ existed in most of the LP during the summer period. This widespread increase is mostly the result of improved water availability to satisfy the evaporative demand, because the precipitation on the LP is mainly concentrated in the summer [17,67]; thus, the soil moisture is recharged by precipitation in this period.

Based on four groups of simulations under future climate and land cover conditions, annual ET had increasing trends on the LP with varied magnitude under RCP4.5 and RCP8.5 scenarios. These findings were consistent with a previous study [68], in which the significantly increasing trends are predicted in southeastern LP under RCP4.5 and RCP8.5 scenarios using the 28 general circulation models. We found that climate change exerted a greater impact on TET than vegetation cover change, which matched previous studies well. For example, Peel et al. (2010) studied relationships between forestation and catchment evapotranspiration from over 200 paired catchments around the world and found that 
non-forested catchments generally have higher actual ET than forested catchments and suggested that the leading factor of ET varied in climate types and depended on the availability of energy and water [19]. Li et al. [24] quantitatively separated the effects of climate change and land cover change on ET in China during the period of 2001-2013 and concluded that the influences of climate change were greater than those of land cover change on ET. Gao et al. [58] used the Budyko Framework to simulate the actual ET in 161 subbasins from 1990 to 2014 on the LP and found that the increase in regional ET was mainly due to the increase in regional precipitation. The LP region has become wetter since the implementation of the Green for Grain Project, with a significant increasing precipitation trend at a rate of $4.46 \mathrm{~mm}$ /year during 1998-2014 [69], which is beneficial to the water availability for VR and further increases the ET on the LP.

Some inconsistent results can also be found in regions of the LP, showing that vegetation greening was the dominant driving factor of ET increase in most LP region [45,46]. These conclusions were obtained from a remote sensing-based ET calculation model and partial correlation analysis between ET and some driving factors; however, due to the limited consideration of the biogeophysical mechanism in ET partitioning, the model had uncertainties in estimating ET components [57]. Additionally, the controlled factor was identified based on correlations between independent climatic variables and ET. While the reality is that these variables are not totally independent, their interactions may also play important roles in the ET trends.

Although the impacts of VR and climate change on ET were identified by combining GLEAM-ET dataset with CLM, some uncertainties remain. As reference data for validating the ET simulation of CLM, GLEAM-ET was used with a set of algorithms that used satellite forcing data, and the ET components were calculated using the Priestley-Taylor method, which does not incorporate parameterization of stomatal and aerodynamic resistance. Although GLEAM-ET has been validated against eddy covariance towers worldwide, that datasets were closer to the flux tower measurements at grassland system followed by the forest and cropland dominated regions [70]; however, cropland covers approximately $38 \%$ of the land area on the LP [57], where the uncertainties existed in the process of CLM validation, but we did not have a better choice at the regional scale. The understanding of spatiotemporal pattern of ET were obtained using grid-based evaluation statistics, which is more or less subjective, because it precludes spatial analysis; thus, distribution-based field significance are more meaningful [71]. In the sensitivity simulations, the Qian ATM forcing data were used repeatedly to force the CLM, and the vegetation cover conditions of 2000 and 2015 were used for model inputs to assess the ET responses, while the magnitude of vegetation growth might not be large enough to cause significant changes in ET, leading to biased results. Additionally, the relative contributions of VR and climate change were identified through scenario simulation under predicted future climate conditions, while current land surface models commonly underestimate the ratio of plant transpiration to total ET [72], which might contribute to the uncertainty in ET prediction under future climate scenarios.

\section{Conclusions}

Along with the implementation of VR, vegetation coverage clearly increases on the LP, inevitably causing TET change. This change involves not only the magnitudes of TET, but also the directions of TET components. In this study, we have quantified the contributions of VR and climate change to TET by analyzing a GLEAM-ET dataset and conducting sensitivity simulations with the CLM. Although GE and CET had larger responses to VR in the southeastern LP, where the LAI of forest and grass clearly increased, the TET had weak change due to the balance between the negative response of GE and positive response of CET. We also found the TET, GE, and CET were especially sensitive to climate change relative to VR, implying that the relative contribution of VR to regional ET may be overestimated in the LP by previous studies, because considering climate factors separately to assess the relative contributions of climate change to ET may mask actual 
signals. Although there were some uncertainties regarding the data inputs and model parametrization, our results highlight the importance of evaluating ET response to VR under various climate conditions with the interactions among climate factors. Moreover, to ensure the sustainability of vegetation restoration on the LP, reducing evaporative water loss and maintaining soil water availability are required. For this purpose, policymakers should pay more attention to land cover management and take positive steps to slow climate warming.

Author Contributions: Conceptualization, L.Q. and Y.W.; formal analysis, L.Q., Z.S., and F.Z.; funding acquisition, L.Q. and Y.W.; methodology, L.Q., Z.S., and Y.C.; validation, Z.S.; visualization, Z.S. and Y.C.; writing—original draft, L.Q.; writing_-review and editing, Y.W. All authors have read and agreed to the published version of the manuscript.

Funding: This study was financially supported by the National Natural Science Foundation of China (32071590, 31961143011), the Strategic Priority Research Program of Chinese Academy of Sciences (XDB40000000), the Natural Science Foundation in Shaanxi Province of China (2019JM-457), Innovation Team of Shaanxi Province in China (2021TD-52) and the Fundamental Research Funds for the Central Universities (xzy012019011).

Data Availability Statement: The data presented in this study are available on request from the corresponding author for research purposes.

Acknowledgments: We thank the HPCC Platform at Xi'an Jiaotong University for the computing equipment and computer maintenance.

Conflicts of Interest: The authors declare no conflict of interest.

\section{References}

1. Komatsu, H.; Kume, T. Modeling of evapotranspiration changes with forest management practices: A genealogical review. J. Hydrol. 2020, 585, 124835. [CrossRef]

2. Cherif, I.; Alexandridis, T.K.; Jauch, E.; Chambel-Leitao, P.; Almeida, C. Improving remotely sensed actual evapotranspiration estimation with raster meteorological data. Int. J. Remote Sens. 2015, 36, 4606-4620. [CrossRef]

3. Zeng, Z.; Piao, S.; Lin, X.; Yin, G.; Peng, S.; Ciais, P.; Myneni, R.B. Global evapotranspiration over the past three decades: Estimation based on the water balance equation combined with empirical models. Environ. Res. Lett. 2012, 7, 014026. [CrossRef]

4. Li, X.; He, Y.; Zeng, Z.; Lian, X.; Wang, X.; Du, M.; Jia, G.; Li, Y.; Ma, Y.; Tang, Y.; et al. Spatiotemporal pattern of terrestrial evapotranspiration in China during the past thirty years. Agric. For. Meteorol. 2018, 259, 131-140. [CrossRef]

5. De Oliveira, R.G.; Valle Júnior, L.C.G.; da Silva, J.B.; Espíndola, D.A.L.F; Lopes, R.D.; Nogueira, J.S.; Curado, L.F.A.; Rodrigues, T.R. Temporal trend changes in reference evapotranspiration contrasting different land uses in southern Amazon basin. Agric. Water Manag. 2021, 250, 106815. [CrossRef]

6. Kundu, S.; Khare, D.; Mondal, A. Interrelationship of rainfall, temperature and reference evapotranspiration trends and their net response to the climate change in Central India. Theor. Appl. Climatol. 2017, 130, 879-900. [CrossRef]

7. Odongo, V.O.; van Oel, P.R.; van der Tol, C.; Su, Z. Impact of land use and land cover transitions and climate on evapotranspiration in the Lake Naivasha Basin, Kenya. Sci. Total Environ. 2019, 682, 19-30. [CrossRef]

8. Eichelmann, E.; Hemes, K.S.; Knox, S.H.; Oikawa, P.Y.; Chamberlain, S.D.; Sturtevant, C.; Verfaillie, J.; Baldocchi, D.D. The effect of land cover type and structure on evapotranspiration from agricultural and wetland sites in the Sacramento-San Joaquin River Delta, California. Agric. Forest Meteorol. 2018, 256, 179-195. [CrossRef]

9. Douville, H.; Ribes, A.; Decharme, B.; Alkama, R.; Sheffield, J. Anthropogenic influence on multidecadal changes in reconstructed global evapotranspiration. Nat. Clim. Chang. 2013, 3, 59-62. [CrossRef]

10. Zeng, R.; Cai, X. Climatic and terrestrial storage control on evapotranspiration temporal variability: Analysis of river basins around the world. Geophys. Res. Lett. 2016, 43, 185-195. [CrossRef]

11. Miralles, D.G.; van den Berg, M.J.; Gash, J.H.; Parinussa, R.M.; de Jeu, R.A.M.; Beck, H.E.; Holmes, T.R.H.; Jimenez, C.; Verhoest, N.E.C.; Dorigo, W.A.; et al. El Nino-La Nina cycle and recent trends in continental evaporation. Nat. Clim. Chang. 2014, 4, 122-126. [CrossRef]

12. Guo, D.; Westra, S.; Maier, H.R. Sensitivity of potential evapotranspiration to changes in climate variables for different Australian climatic zones. Hydrol. Earth Syst. Sci. 2017, 21, 2107-2126. [CrossRef]

13. Wang, Z.; Xie, P.; Lai, C.; Chen, X.; Wu, X.; Zeng, Z.; Li, J. Spatiotemporal variability of reference evapotranspiration and contributing climatic factors in China during 1961-2013. J. Hydrol. 2017, 544, 97-108. [CrossRef]

14. Pour, S.H.; Abd Wahab, A.K.; Shahid, S.; Bin Ismail, Z. Changes in reference evapotranspiration and its driving factors in peninsular Malaysia. Atmos. Res. 2020, 246. [CrossRef] 
15. Roderick, M.L.; Farquhar, G.D. The cause of decreased pan evaporation over the past 50 years. Science 2002, $298,1410-1411$. [CrossRef] [PubMed]

16. Forbes, K.A.; Kienzle, S.W.; Coburn, C.A.; Byrne, J.M.; Rasmussen, J. Simulating the hydrological response to predicted climate change on a watershed in southern Alberta, Canada. Clim. Chang. 2011, 105, 555-576. [CrossRef]

17. Qiu, L.; Wu, Y.; Wang, L.; Lei, X.; Liao, W.; Hui, Y.; Meng, X. Spatiotemporal response of the water cycle to land use conversions in a typical hilly-gully basin on the Loess Plateau, China. Hydrol. Earth Syst. Sci. 2017, 21, 6485-6499. [CrossRef]

18. Liu, Y.; Xiao, J.; Ju, W.; Xu, K.; Zhou, Y.; Zhao, Y. Recent trends in vegetation greenness in China significantly altered annual evapotranspiration and water yield. Environ. Res. Lett. 2016, 11. [CrossRef]

19. Peel, M.C.; McMahon, T.A.; Finlayson, B.L. Vegetation impact on mean annual evapotranspiration at a global catchment scale. Water Resour. Res. 2010, 46. [CrossRef]

20. Yao, Y.; Liang, S.; Cheng, J.; Lin, Y.; Jia, K.; Liu, M. Impacts of deforestation and climate variability on terrestrial evapotranspiration in subarctic China. Forests 2014, 5, 2542-2560. [CrossRef]

21. Teuling, A.J.; de Badts, E.A.G.; Jansen, F.A.; Fuchs, R.; Buitink, J.; van Dijke, A.J.H.; Sterling, S.M. Climate change, reforestation/afforestation, and urbanization impacts on evapotranspiration and streamflow in Europe. Hydrol. Earth Syst. Sci. 2019, 23, 3631-3652. [CrossRef]

22. Sun, G.; McNulty, S.G.; Lu, J.; Amatya, D.M.; Liang, Y.; Kolka, R.K. Regional annual water yield from forest lands and its response to potential deforestation across the southeastern United States. J. Hydrol. 2005, 308, 258-268. [CrossRef]

23. Aladejana, O.O.; Salami, A.T.; Adetoro, O.-I.O. Hydrological responses to land degradation in the Northwest Benin Owena River Basin, Nigeria. J. Environ. Manag. 2018, 225, 300-312. [CrossRef] [PubMed]

24. Li, G.; Zhang, F.; Jing, Y.; Liu, Y.; Sun, G. Response of evapotranspiration to changes in land use and land cover and climate in China during 2001-2013. Sci. Total Environ. 2017, 596-597, 256-265. [CrossRef]

25. Shanafield, M.; Gutierrez-Jurado, H.; Eliana Rodriguez-Burgueno, J.; Ramirez-Hernandez, J.; Jarchow, C.J.; Nagler, P.L. Short- and long-term evapotranspiration rates at ecological restoration sites along a large river receiving rare flow events. Hydrol. Process. 2017, 31, 4328-4337. [CrossRef]

26. Rigden, A.J.; Salvucci, G.D. Stomatal response to humidity and $\mathrm{CO}_{2}$ implicated in recent decline in US evaporation. Glob. Chang. Biol. 2017, 23, 1140-1151. [CrossRef]

27. Kergoat, L.; Lafont, S.; Douville, H.; Berthelot, B.; Dedieu, G.; Planton, S.; Royer, J.F. Impact of doubled CO $\mathrm{CO}_{2}$ on global-scale leaf area index and evapotranspiration: Conflicting stomatal conductance and LAI responses. J. Geophys. Res. Atmos. 2002, 107. [CrossRef]

28. Wang, H.; Lv, X.; Zhang, M. Sensitivity and attribution analysis of vegetation changes on evapotranspiration with the Budyko framework in the Baiyangdian catchment, China. Ecol. Indic. 2021, 120, 106963. [CrossRef]

29. Liu, Z.; Cheng, L.; Zhou, G.; Chen, X.; Lin, K.; Zhang, W.; Chen, X.; Zhou, P. Global response of evapotranspiration ratio to climate conditions and watershed characteristics in a changing environment. J. Geophys. Res. Atmos. 2020, 125. [CrossRef]

30. Kundu, S.; Mondal, A.; Khare, D.; Hain, C.; Lakshmi, V. Projecting climate and land use change impacts on actual evapotranspiration for the Narmada River basin in central India in the future. Remote Sens. 2018, 10, 578. [CrossRef]

31. Lamchin, M.; Lee, W.-K.; Jeon, S.W.; Wang, S.W.; Lim, C.H.; Song, C.; Sung, M. Long-term trend and correlation between vegetation greenness and climate variables in Asia based on satellite data. Sci. Total Environ. 2018, 618, 1089-1095. [CrossRef]

32. Jahangir, M.H.; Arast, M. Remote sensing products for predicting actual evapotranspiration and water stress footprints under different land cover. J. Clean. Prod. 2020, 266, 121818. [CrossRef]

33. Hagan, D.F.T.; Wang, G.; Liang, X.S.; Dolman, H.A.J. A time-varying causality formalism based on the Liang-Kleeman information flow for analyzing directed interactions in nonstationary climate systems. J. Clim. 2019, 32, 7521-7537. [CrossRef]

34. Bohn, T.J.; Vivoni, E.R. Process-based characterization of evapotranspiration sources over the North American monsoon region. Water Resour. Res. 2016, 52, 358-384. [CrossRef]

35. Gao, G.; Fu, B.; Wang, S.; Liang, W.; Jiang, X. Determining the hydrological responses to climate variability and land use/cover change in the Loess Plateau with the Budyko framework. Sci. Total Environ. 2016, 557, 331-342. [CrossRef] [PubMed]

36. Wang, Y.; Zhang, S.; Chang, X. Evapotranspiration estimation based on remote sensing and the SEBAL model in the Bosten Lake basin of China. Sustainability 2020, 12, 7293. [CrossRef]

37. Su, Z. The Surface Energy Balance System (SEBS) for estimation of turbulent heat fluxes. Hydrol. Earth Syst. Sci. 2002, 6, 85-99. [CrossRef]

38. Lei, H.; Huang, M.; Leung, L.R.; Yang, D.; Shi, X.; Mao, J.; Hayes, D.J.; Schwalm, C.R.; Wei, Y.; Liu, S. Sensitivity of global terrestrial gross primary production to hydrologic states simulated by the Community Land Model using two runoff parameterizations. J. Adv. Model. Earth Syst. 2014, 6, 658-679. [CrossRef]

39. Shi, X.; Mao, J.; Thornton, P.E.; Huang, M. Spatiotemporal patterns of evapotranspiration in response to multiple environmental factors simulated by the Community Land Model. Environ. Res. Lett. 2013, 8. [CrossRef]

40. Bonan, G.B.; Doney, S.C. Climate, ecosystems, and planetary futures: The challenge to predict life in Earth system models. Science 2018, 359, 6375. [CrossRef]

41. Fu, B.; Wang, S.; Liu, Y.; Liu, J.; Liang, W.; Miao, C. Hydrogeomorphic ecosystem responses to natural and anthropogenic changes in the Loess Plateau of China. Annu. Rev. Earth Planet. Sci. 2017, 45, 223-243. [CrossRef] 
42. Miao, C.; Ni, J.; Borthwick, A.G.L. Recent changes of water discharge and sediment load in the Yellow River basin, China. Prog. Phys. Geogr. 2010, 34, 541-561. [CrossRef]

43. Feng, X.; Fu, B.; Piao, S.; Wang, S.; Ciais, P.; Zeng, Z.; Lu, Y.; Zeng, Y.; Li, Y.; Jiang, X.; et al. Revegetation in China's Loess Plateau is approaching sustainable water resource limits. Nat. Clim. Chang. 2016, 6, 1019-1022. [CrossRef]

44. Li, C.; Wu, P.T.; Li, X.L.; Zhou, T.W.; Sun, S.K.; Wang, Y.B.; Luan, X.B.; Yu, X. Spatial and temporal evolution of climatic factors and its impacts on potential evapotranspiration in Loess Plateau of Northern Shaanxi, China. Sci. Total Environ. 2017, 589, 165-172. [CrossRef] [PubMed]

45. Bai, M.; Mo, X.; Liu, S.; Hu, S. Contributions of climate change and vegetation greening to evapotranspiration trend in a typical hilly-gully basin on the Loess Plateau, China. Sci. Total Environ. 2019, 657, 325-339. [CrossRef]

46. Jin, Z.; Liang, W.; Yang, Y.T.; Zhang, W.B.; Yan, J.W.; Chen, X.J.; Li, S.; Mo, X.G. Separating vegetation greening and climate change controls on evapotranspiration trend over the Loess Plateau. Sci. Rep. 2017, 7, 15. [CrossRef] [PubMed]

47. Pei, T.; Wu, X.; Li, X.; Zhang, Y.; Shi, F.; Ma, Y.; Wang, P.; Zhang, C. Seasonal divergence in the sensitivity of evapotranspiration to climate and vegetation growth in the Yellow River Basin, China. J. Geophys. Res. Biogeosci. 2017, 122, 103-118. [CrossRef]

48. Oleson, K.W.; Lawrence, D.M.; Gordon, B.; Flanner, M.G.; Kluzek, E.; Peter, J.; Levis, S.; Swenson, S.C.; Thornton, E. Technical description of version 4.0 of the Community Land Model (CLM). 2010. Available online: http:/ / citeseerx.ist.psu.edu/viewdoc/ summary?doi=10.1.1.172.7769 (accessed on 6 January 2021).

49. Miralles, D.G.; Holmes, T.R.H.; De Jeu, R.A.M.; Gash, J.H.; Meesters, A.G.C.A.; Dolman, A.J. Global land-surface evaporation estimated from satellite-based observations. Hydrol. Earth Syst. Sci. 2011, 15, 453-469. [CrossRef]

50. Martens, B.; Miralles, D.G.; Lievens, H.; van der Schalie, R.; de Jeu, R.A.M.; Fernandez-Prieto, D.; Beck, H.E.; Dorigo, W.A.; Verhoest, N.E.C. GLEAM v3: Satellite-based land evaporation and root-zone soil moisture. Geosci. Model. Dev. 2017, 10, 1903-1925. [CrossRef]

51. Qian, T.; Dai, A.; Trenberth, K.E.; Oleson, K.W. Simulation of global land surface conditions from 1948 to 2004 . Part I: Forcing data and evaluations. J. Hydrometeorol. 2006, 7, 953-975. [CrossRef]

52. Xiao, Z.; Liang, S.; Wang, J.; Xiang, Y.; Zhao, X.; Song, J. Long-Time-Series global land surface satellite leaf area index product derived from MODIS and AVHRR surface reflectance. IEEE Trans. Geosci. Remote Sens. 2016, 54, 5301-5318. [CrossRef]

53. Van Vuuren, D.P.; Edmonds, J.; Kainuma, M.; Riahi, K.; Thomson, A.; Hibbard, K.; Hurtt, G.C.; Kram, T.; Krey, V.; Lamarque, J.-F.; et al. The representative concentration pathways: An overview. Clim. Chang. 2011, 109, 5-31. [CrossRef]

54. Sanikhani, H.; Kisi, O.; Maroufpoor, E.; Yaseen, Z.M. Temperature-based modeling of reference evapotranspiration using several artificial intelligence models: Application of different modeling scenarios. Theor. Appl. Climatol. 2019, 135, 449-462. [CrossRef]

55. Wu, F.; Wang, X.; Cai, Y.; Yang, Z.; Li, C. Spatiotemporal analysis of temperature-variation patterns under climate change in the upper reach of Mekong River basin. Sci. Total Environ. 2012, 427, 208-218. [CrossRef]

56. Gao, X.; Sun, M.; Luan, Q.; Zhao, X.; Wang, J.; He, G.; Zhao, Y. The spatial and temporal evolution of the actual evapotranspiration based on the remote sensing method in the Loess Plateau. Sci. Total Environ. 2020, 708, 135111. [CrossRef]

57. Ma, Z.; Yan, N.; Wu, B.; Stein, A.; Zhu, W.; Zeng, H. Variation in actual evapotranspiration following changes in climate and vegetation cover during an ecological restoration period (2000-2015) in the Loess Plateau, China. Sci. Total Environ. 2019, 689, 534-545. [CrossRef] [PubMed]

58. Gao, X.; Sun, M.; Zhao, Q.; Wu, P.; Zhao, X.; Pan, W.; Wang, Y. Actual ET modelling based on the Budyko framework and the sustainability of vegetation water use in the loess plateau. Sci. Total Environ. 2017, 579, 1550-1559. [CrossRef]

59. Shao, R.; Zhang, B.; Su, T.; Biao, L.; Cheng, L.; Xue, Y.; Yang, W. Estimating the increase in regional evaporative water consumption as a result of vegetation restoration over the Loess Plateau, China. J. Geophys. Res. Biogeosci. 2019, 124, 11783-11802. [CrossRef]

60. Miralles, D.G.; Gash, J.H.; Holmes, T.R.H.; de Jeu, R.A.M.; Dolman, A.J. Global canopy interception from satellite observations. J. Geophys. Res. Biogeosci. 2010, 115. [CrossRef]

61. Herbst, M.; Rosier, P.T.W.; McNeil, D.D.; Harding, R.J.; Gowing, D.J. Seasonal variability of interception evaporation from the canopy of a mixed deciduous forest. Agric. For. Meteorol. 2008, 148, 1655-1667. [CrossRef]

62. Jackson, N.A.; Wallace, J.S. Soil evaporation measurements in an agroforestry system in Kenya. Agric. For. Meteorol. 1999, 94, 203-215. [CrossRef]

63. Allen, S.T.; Reba, M.L.; Edwards, B.L.; Keim, R.F. Evaporation and the subcanopy energy environment in a flooded forest. Hydrol. Process. 2017, 31, 2860-2871. [CrossRef]

64. Magliano, P.N.; Gimenez, R.; Houspanossian, J.; Paez, R.A.; Nosetto, M.D.; Fernandez, R.J.; Jobbagy, E.G. Litter is more effective than forest canopy reducing soil evaporation in Dry Chaco rangelands. Ecohydrology 2017, 10. [CrossRef]

65. Raz-Yaseef, N.; Rotenberg, E.; Yakir, D. Effects of spatial variations in soil evaporation caused by tree shading on water flux partitioning in a semi-arid pine forest. Agric. For. Meteorol. 2010, 150, 454-462. [CrossRef]

66. Miralles, D.G.; De Jeu, R.A.M.; Gash, J.H.; Holmes, T.R.H.; Dolman, A.J. Magnitude and variability of land evaporation and its components at the global scale. Hydrol. Earth Syst. Sci. 2011, 15, 967-981. [CrossRef]

67. Zhao, G.; Mu, X.; Wen, Z.; Wang, F.; Gao, P. Soil erosion, conservation, and eco-environment changes in the Loess Plateau of China. Land Degrad. Dev. 2013, 24, 499-510. [CrossRef]

68. Peng, S.; Ding, Y.; Wen, Z.; Chen, Y.; Cao, Y.; Ren, J. Spatiotemporal change and trend analysis of potential evapotranspiration over the Loess Plateau of China during 2011-2100. Agric. For. Meteorol. 2017, 233, 183-194. [CrossRef] 
69. Zhao, Q.; Chen, Q.; Jiao, M.; Wu, P.; Gao, X.; Ma, M.; Hong, Y. The temporal-spatial characteristics of drought in the Loess Plateau using the remote-sensed TRMM precipitation data from 1998 to 2014. Remote Sens. 2018, 10, 838. [CrossRef]

70. Yang, X.; Yong, B.; Ren, L.; Zhang, Y.; Long, D. Multi-scale validation of GLEAM evapotranspiration products over China via ChinaFLUX ET measurements. Int. J. Remote Sens. 2017, 38, 5688-5709. [CrossRef]

71. Ivanov, M.; Warrach-Sagi, K.; Wulfmeyer, V. Field significance of performance measures in the context of regional climate model evaluation. Part 2: Precipitation. Theor. Appl. Climatol. 2018, 132, 239-261. [CrossRef]

72. Zeng, Z.; Piao, S.; Li, L.Z.X.; Zhou, L.; Ciais, P.; Wang, T.; Li, Y.; Lian, X.; Wood, E.F.; Friedlingstein, P.; et al. Climate mitigation from vegetation biophysical feedbacks during the past three decades. Nat. Clim. Chang. 2017, 7, 432-436. [CrossRef] 